\title{
MODERN MODELS OF PROVIDING AUTONOMY OF HIGHER EDUCATIONAL INSTITUTIONS (ANALYSIS OF FOREIGN COUNTRIES EXPERIENCE)
}

\author{
Ilyosjon Bakhromovich Siddikov
}

Senior Lecturer (PhD) Fergana State University

\section{ABSTRACT}

In this article, the process of ensuring the autonomy of higher education institutions in the developing countries of the world, the main tools, factors and models in this regard have been studied. Also in the article, the importance of ensuring academic freedom in ensuring the quality of education in higher educational institutions, the peculiarities of the autonomy of higher educational institutions as an institutional form of academic freedom are analyzed by the example of foreign state experience.

KEYWORDS:- Higher education, institution of higher learning, autonomy, academic freedom, quality of Education, Foreign experience, model, academic mobility, educational process, educational autonomy, autonomous education, strategy of Higher Education.

\section{INTRODUCTION}

By the end of the twentieth century, the goals and objectives of the university as a sociocultural object were formed: to create conditions for personal development, preservation and transmission of cultural and scientific heritage, expansion and dissemination of knowledge. Achieving these goals will be achieved through decentralization of the management of higher education institutions (transition from a centralized to a decentralized system) and the transfer of a number of powers. The transfer of power is intended to end the government's tight control over higher education. This will help to form the personal profile of higher education institutions and expand their autonomy. As a principle of higher education management, the autonomy of higher education institutions reflects its level of decentralization, leading to self-organization, self-governance and selfregulation. In general, the autonomy of higher education institutions refers to its development strategy, organizational system, selection and placement of personnel, educational, research, financial, economic, international and higher education institutions. independence in the implementation of other types of activities in accordance with the regulations and applicable national laws.

In the scientific literature, the autonomy of higher education institutions is interpreted as an institutional form of academic freedom. The following provisions clarify this thesis. First, it is 
manifested in the substantiation of the university's special role as a source of knowledge, collector, custodian, and translator.

Second, academic freedom logically stems from Descartes 'theory of knowledge. According to him, the process of cognition requires freedom from external control. In this case, the academic environment at the university represents a particular reality and requires educational autonomy to achieve its goals and requirements.

Third, this is explained by the growing role of universities in a post-industrial society.

\section{Materials AND MEthods}

Ensuring a strong link between the autonomy of European higher education institutions, their responsibilities and the quality of education is an important requirement of the Bologna process. According to researcher Yu.Timm, the autonomy of higher education institutions does not mean absolute freedom, because it implies not only the budget of the public institution, the goals and objectives set by society and the state, but also the quality of higher education and the benefits that graduates can bring [ 1, p.232, 23-31.]. Krontaler argues that autonomy is not a privilege for higher education. Not only does it bring dividends, but it is also a huge amount of duty and responsibility that no higher education institution can handle. The degree of autonomy an employee or institution receives should depend on the level of development they have achieved.

Everyone has different levels of independence in choosing a life path and making decisions. Autonomy cannot be forced into higher education. The pursuit of autonomy must be studied, because independence is always associated with a high level of responsibility [2, p.147, 48-53.].

The 1990s saw a dramatic increase in the development of Russian higher education. They were given free management of the property. A wide range of rights were granted and large tax breaks were granted (later abolished). The state freed universities from ideological patronage that hindered academic development during the Soviet era. At the same time, the state deprived universities of the right to use public financial resources. This has led to the search for funds and livelihoods, as well as the loss of staff.

In an effort to overcome the negative trend of academic autonomy, which means that everything is allowed, Russian universities began to move towards social quality monitoring, relying on international standards and management concepts prevalent in Europe and the United States [3, p.44-49.] .

One of them is the concept of "new social governance", which became widespread in the 80 s of the twentieth century. In European countries, this concept is aimed at expanding the autonomy of higher education institutions, the allocation of funds "on the basis of results", the formation of "global budgets", the mutual obligations of the parties with the administration and faculty of higher education. meant reforms aimed at coordinating goals. The former academic self-government system has been criticized for its conservatism and inability to meet the demands of the times. Increased elements of competition and rivalry between higher education institutions require the search for new sources of funding and the expansion of the resource base that is being attracted due to the chronic decline in public funding.

The specialization of higher education institutions and their openness to society significantly strengthens the competition between universities for attracting students, extra-budgetary funds, and encourages them to 
CURRENT RESEARCH JOURNAL OF PEDAGOGICS 2(5): 25-31, May 2021

DOI: https://doi.org/10.37547/pedagogics-crjp-02-05-05

ISSN 2767-3278

(C)2021 Master Journals

\section{Crossref do) 8 Google}

Accepted 15 th May, 2021 \& Published 20 ${ }^{\text {th }}$ May, 2021

activate internal resources. At the same time, the management system of higher education institutions is being modernized, and professionalization at various levels of government (rector's office, dean's office, etc.) is increasing. This is done on a contract basis to hire business-minded, strategic managers.

At the same time, there is a declining trend towards classic self-government based on collegial (collective) leadership and collective responsibility. The academic community is a thing of the past as a key player in governance.

German researchers Yu. Lantsendorf and P. Pasternak analyzed the laws on higher education in a number of federal districts in Germany and found that almost all of them strengthened the new principles of social governance, regardless of which party members belonged to which party. The authors include in such principles, first of all, the principle of expanding the institutional autonomy of the higher school. The above principles envisage the reduction of bureaucratic orders and directives on budget and personnel management, and the formation of the chamber (eliminating the need to review the collected data in the cabinet, flexibility of the staffing table, reduction of external control functions, independent implementation of the teaching staff on a selective basis) [4, p. 168]. In this case, professors lose the status of civil servants. The system of remuneration of professors and teachers will change and it will encourage higher results in education and research.

In Germany, new organizational and legal forms of university activity have been introduced in order to attract additional sources of funding and expand the autonomy of higher education institutions. In Lower Saxony, for example, funded universities have been introduced, the founders of which may be public or private foundations. The advantage of funded universities is that they have access to multichannel funding. The University of Hildesheim is one of the fund universities in Lower Saxony. Based on this, the partner universities jointly implement bachelor's and master's degree programs in pedagogy, which entitle the holder to two diplomas. The University of Frankfurt am Main has received a new form of funded university in Gessen. However, in some federal states (Berlin, Bremen, McLenberg - Old Pomerania) it is not possible to choose the organizational and legal form of higher education.

Researchers R. Munch and M. Pexmann propose a comprehensive examination as a tool for managing the quality of higher education. In this case, the strengthening of the spirit of competition becomes a management tool, and this process takes place not only among scientists, but also among the universities, which are taken separately as an organization. According to the authors, currently complex expertise measures are not perfect, as they focus almost entirely on quantitative indicators and pay almost no attention to the scientific and educational process.

The authors attribute the imperfection of the complex expertise of European universities to the "Matthew effect" ("money brings money"), and additional funding will be sent to universities that are already well funded. The accumulation of funds in such a place will help to create monopolistic universities, but they will not be able to use these funds effectively. In addition, complex examinations and ratings conducted in this way lead to the formalization and standardization of scientific research and, in essence, the squeezing of the creative basis from them [4, p.67-92].

Researchers S. Gerber, Y. Bogumil, R. Heinze, and S. Gross propose university councils as an important tool of governance. Because they 
provide an opportunity to involve external experts and social partners in the management of the university, as representatives of various spheres of activity. Such councils operate in all regions of Germany except Bremen. Sometimes several universities work together, as an exception, to form a single council. In some cases, councils are formed from external experts. This narrows their spectrum of competence and prevents them from making a number of important management decisions. Boards with mixed composition perform management functions more efficiently. Strengthening university councils weakens the functions of involuntary academic councils. The appointment or election of university administrators remains controversial. In six federal districts, this new governing body was the main function of the university councils, while in the rest it was left to academic councils or community conferences [4, pp.93-122].

\section{Result AND DisCUSSION}

Within the framework of the concept of "new social management", the process of determining the ways to achieve the goals of the first level, which is a key part of national policy, has been established. and distinguish the organizationalstructural autonomy that gives the right to determine the private academic system. [5, p. 147-155]

The basis for the development of financial and institutional autonomy of higher education institutions in Russia is, first of all, autonomous institutions that are more focused on commercial sources of funding. This includes changing the status of higher education institutions, ensuring economic independence and competitiveness of educational services in the world market. A number of federal universities have the status of autonomous institutions. Southern and Siberian federal universities were the first in Russia to receive autonomous status. Now these universities, like all government agencies, receive state funding not as an estimate, but as a subsidy, and their size depends on the tasks to be solved at the university.

At the same time, it is important that the Southern and Siberian federal universities have economic freedom in spending the funds at their disposal: they voluntarily reduce spending on some areas and increase salaries on others, including salaries. they can spread. The dispositive rule on the establishment of boards of trustees in higher education institutions has been replaced in the legislation by specific norms for the establishment of them in federal universities.

Based on the analysis of the world practice of higher education, the autonomy of the university can be divided into liberal and centrist models.

The liberal model (USA, UK, Canada) is characterized by a wide range of autonomy of higher education institutions. The role of the ministries of education and the authorities in this will be to formulate strategic priorities and parameters for the development of the higher education system.

The main part of the management authority is concentrated in the hands of intermediary organizations (usually state-owned or professional social organizations), which are responsible for licensing and accreditation of educational programs, ensuring the quality of education, financial can perform the function of resource allocation and so on.

In the United States, the signs of institutional autonomy are clear enough. Because the market, which reduces the leading role of the state and provides multi-channel funding for American universities, is important, as well as the support 
of the state from various grants, projects and contracts, tuition fees, charitable foundations. , also earns income from the sale of scientific and educational services. Boards of Trustees play an important role in mediating between the university and the community.

Under the centrist model (France, Germany, Russia, Ukraine), higher education institutions are legally autonomous in their teaching, research, administrative and financial activities. In addition, the university's relations with the state are governed by legislation, orders and directives of public authorities.

The structure and tasks of higher education institutions, curricula and programs, despite the renewal of university autonomy, are to some extent determined by the guidelines of public authorities on education management, and they address urgent issues related to the activities of higher education institutions.

From the above, it can be seen that the trend of autonomy has primarily affected the centrist model and is reflected in the following three aspects of the autonomy of public universities: administrative, financial, and pedagogical.

Administrative autonomy includes the appointment of the rector through elections, the right to appoint vice-rectors, the right to independently compile and approve the staffing of higher education institutions, the formation of the internal structure of management, the creation of organizational units, etc.

Financial autonomy Free access to state funds, as well as other private and public funds provided to higher education institutions; provision of paid educational services; the right to use the income from independent activities at its own discretion.

Pedagogical autonomy implies independence in the development of curricula and programs, the choice of teaching methods and areas of research, the choice of methods of knowledge testing and final certification.

Based on the nature of the relationship with the state and the specifics of university funding, a number of authors distinguish three main models.

The market model assumes that universities are legally autonomous and independent (USA, Canada, Australia and Japan). The main features of the education system in countries with a market model are: strong decentralization in governance (various educational institutions are subordinated to local, professional governing bodies or committees and commissions of the states); pluralism in the establishment of educational institutions (lack of state monopoly in the establishment of educational institutions); diversity of educational institutions and their programs.

For example, the difference between American universities and others is that when you move from one institution to another, you have to take into account the points you have accumulated in the amount of knowledge you have acquired in the subjects. is calculated.

When the directive model is used, higher education institutions are governed by the central government (for example, in South Korea). In this case, the financial, material and organizational-legal management of the education system is carried out in a centralized manner. Public administration is carried out using authoritarian methods and Confucian principles of life. Education is administered at three administrative levels: the Ministry of Education, provincial and municipal departments.

The mixed model university can be described as a federal system with a certain degree of autonomy, limited by law (China). China's Higher Education Administration is governed by the 
CURRENT RESEARCH JOURNAL OF PEDAGOGICS 2(5): 25-31, May 2021

DOI: https://doi.org/10.37547/pedagogics-crjp-02-05-05

ISSN 2767-3278

(C)2021 Master Journals

Crossref dof 81 Google

Accepted 15th May, 2021 \& Published 20 ${ }^{\text {th }}$ May, 2021

State Council, provincial people's governments, autonomous regions, and centralized cities. The new education strategy envisages decentralization and privatization, democratization and humanization based on national theories and world experience. It includes medium scales, system optimization and various forms of educational institutions, focus on regional development, transparency of the education system [6, p. 324].

\section{Conclusion}

Conclusion, the academic freedom of universities in different countries of the world guarantees the freedom of their internal intellectual life, their management on the basis of liberal principles, and the innovative nature of the development of higher education institutions.

\section{REFERENCES}

1. Timm J. Kontrakt management und Zielvereinbarungen / Reform Universitäten. Leistungsfähigkeit durch Eigen verantwortung.Stifterverband für die Deutsche Wissenschaft (Hrsg.). Bonn, 1999. S.232, 23-31.

2. Kronthaler L. Autonomie muss gelernt werden / Reform Universitäten. Leistungsfähigkeit durch Eigen verantwortung. Stifterverband für die Deutsche Wissenschaft (Hrsg.). Bonn, 1999. S.147, 48-53.

3. Волосникова Л.М. 0 принципе академической автономии// Университетское управление: практика и анализ. 2005.№5. C.44-49.
4. Bogumil J., Heinze R.G. (Hg.) Neue Steuerung von Hochschulen. - Berlin, 2009. $168 \mathrm{~s}$.

5. Никольский В. Университетская автономия и академическая свобода: критический взгляд на взаимосвязь традиционных ценностей // Высшее образование в России.2008. №6. С.147155.

6. Управление современным университетом: Монография /Под ред. Г.И.Лазарева. Владивосток: ВГУЭС, 2005. $324 \mathrm{c}$.

7. Bakhromovich, S. I. (2020). Effects of Objective and Subjective Factors to Develop Intellectual Culture of Youth. Canadian Social Science, 16(2), 55-59.

8. Ahmadjonovna, E. T., \& Bakhromovich, S. I. (2020). Pedagogical Analysis Of CulturoEducational Institutions' Actions In Youth Education (On The Example Of Museum Activities). The American Journal of Social Science and Education Innovations, 2(08), 576-582.

9. Сиддиков, И. Б. (2018). Социальнофилософские аспекты формирования интеллектуальной культуры молодёжи. Theoretical \& Applied Science, (1), 61-66.

10. Bakhromovich, S. I. (2018). Social and philisophical performance of making youth's intellectual culture. European science review, (7-8).

11. Bakhromovich, S. I. (2020). Analysis of Modern Approaches To Ensuring The Effectiveness of Management In Higher Education Institutions. The American Journal of Social Science and Education Innovations, 2(12), 364-369.

12. Siddikov, I., \& Gulomov, A. (2020). Philosophical and psychological features of 
CURRENT RESEARCH JOURNAL OF PEDAGOGICS 2(5): 25-31, May 2021

DOI: https://doi.org/10.37547/pedagogics-crjp-02-05-05

ISSN 2767-3278

(C)2021 Master Journals

crossref do) 801 Google

Accepted 15th May, 2021 \& Published 20 th May, 2021

the formation of asertive behavior in the development of cognitive activity. In Психологическое здоровье населения как важный фактор обеспечения процветания общества (pp. 38-42).4

13. Сиддиков, И. Б. (2019). Государственная политика в отношении молодежи в Узбекистане: национальный опыт и реальная необходимость международных инициатив. In Условия социально-экономического развития общества: история и современность (pp. 38-43).

14. Bakhromovich, S. I. (2020). The impact of managerial professional development on the effectiveness of Higher Education institution management. Academicia: an international multidisciplinary research journal, 10(12), 1014-1020.

15. Siddikov, I. В. (2019). Философскопедагогические аспекты развития интеллектуальной культуры студентов. Вестник Ошского государственного университета, (3), 38-42.

16. Bakhromovich, S. I. Development trends and transformation processes in academic mobility in higher education in Uzbekistan and the world. 